\title{
Implementasi Fungsi Pelayanan Publik dalam Pelayanan Terpadu Satu Pintu (PTSP)
}

\author{
Suhartoyo \\ Fakultas Hukum, Universitas Diponegoro \\ suhartoyo@undip.ac.id
}

\begin{abstract}
This study aims to determine the implementation of the function of public services in onestop integrated services. The research method used is empirical legal research that uses a regulatory approach and a conceptual approach. The results of the study indicate that PTSP system policies can only be an alternative improvement of the One-Stop Service System. However, this new system will not provide the expected changes, if it cannot show an efficient service, has a clear standard of time and costs, has a simple service procedure, and is easily accessible to those in need. To realize an administrative service system that has such characteristics, one of the strategies that needs to be developed in PTSP is through the establishment of a Service Unit (UP) that has special authority in granting licenses. The UP can be designed in several forms, including: First, It is a particular Unit / Unit of Work, which has the authority to provide investment licensing services centrally. This Unit / Work Unit has the authority to process and issue various licenses which constitute a delegation of part of the authority of work units that serve licensing. Second, is a Unit / Work Unit that provides investment licensing services. This unit / work unit has a front line that serves to receive all investment permit applications in the region and a back line that has a working relationship with a unit / work unit that functionally issues licenses.
\end{abstract}

Keywords: One Door Public Service, Government, Community Service

\begin{abstract}
Abstrak
Penelitian ini bertujuan untuk mengetahui implementasi fungsi pelayanan publik dalam pelayanan terpadu satu pintu. Metode penelitian yang digunakan dalah penelitian hukum empiris yang menggunakan pendekatan peraturan perundang undangan dan pendekatan konseptual. Hasil penelitian menujukan bahwa Kebijakan sistem PTSP dapat saja sebagai alternatif perbaikan dari Sistem Pelayanan Satu Atap. Namun demikian, sistem baru ini tidak akan memberikan perubahan yang diharapkan, jika tidak dapat menunjukan adanya efisien dalam pelayanan, memiliki standar waktu dan biaya yang jelas, memiliki prosedur pelayanan yang sederhana, dan mudah diakses oleh yang membutuhkan. Untuk mewujudkan sistem pelayanan administrasi yang memiliki karakter demikian, salah satu strategi yang perlu dikembangkan dalam PTSP adalah melalui pembentukan Unit Pelayanan (UP) yang memiliki kewenangan khusus dalam pemberian perizinan. UP tersebut dapat didesain dalam beberapa bentuk, antara lain: Pertama, Merupakan Satuan/Unit Kerja tertentu, yang memiliki kewenangan untuk memberikan pelayanan perizinan penanaman modal secara terpusat. Satuan/Unit Kerja ini memiliki kewenangan untuk memproses dan menerbitkan berbagai perizinan yang merupakan pelimpahan sebagian dari kewenangan unit-unit kerja yang melayani perizinan. Kedua, Merupakan Satuan/Unit Kerja yang memberikan pelayanan perizinan penanaman modal. Satuan/Unit kerja ini memiliki front line yang berfungsi untuk
\end{abstract}


menerima semua permohonan perizinan penanaman modal di daerah dan back line yang memiliki hubungan kerja dengan satuan/unit kerja yang secara fungsional menerbitkan perizinan.

Kata Kunci: Pelayanan Publik Satu Pintu, Pemerintahan, Layanan Masyarakat

\section{A. Pendahuluan}

Perubahan paradigma pemerintahan merupakan bentuk upaya agar pemerintahan menjadi yang lebih baik lagi terutama dalam melayani masyarakat. Pemerintahan yang kaku dan sentralistik kini telah berubah menjadi pemerintahan yang terdesentralisasi dan memiliki semangat entrepreneur. Perubahan orientasi pelayanan sebagai wujud perbaikan kualitas pelayanan. Untuk itu diperlukan perbaikan kualitas pelayanan secara berkesinambungan demi terwujudnya pelayanan publik yang prima. Perbaikan kualitas pelayanan publik dilakukan secara menyeluruh dan terintegrasi, baik secara internal maupun eksternal perlu dilakukan pembenahan dan membutuhkan manajemen yang tepat [1].

Dalam perbaikan kualitas pelayanan publik, pemerintah menggunakan manajemen publik. Manajemen publik fokus pada internal organisasi sektor publik yaitu bagaimana mengatur organisasi sektor publik bekerja dengan optimal untuk mencapai tujuan, dan tidak mengabaikan eksternal organisasi sektor publik yang selalu dipengaruhi oleh kebijakan publik dan kepentingan politik. Manajemen publik merupakan cabang dari administrasi publik yang secara khusus membahas keilmuan mengenai desain program dan restrukturisasi organisasi, alokasi sumber daya melalui sistem penganggaran, manajemen keuangan, manajemen Sumber Daya Manusia dan evaluasi program dan audit. Manajemen publik juga membahas mengenai kualitas pelayanan publik yang saat ini menjadi sorotan utama, apalagi saat ini pelayanan publik menjadi tugas pemerintah daerah.

Pelayanan publik menjadi topik yang menarik untuk dikaji oleh para ahli dan pemerhati masalah administrasi publik. Pelayanan publik adalah pemenuhan keinginan dan kebutuhan masyarakat oleh penyelenggara negara dan negara didirikan oleh publik dengan tujuan agar dapat meningkatkan kesejahteraan masyarakat. Sinambela mengungkapkan bahwa tujuan pelayanan publik adalah untuk memuaskan masyarakat sebagai pengguna layanan. Dan kepuasan tersebut dapat dicapai dengan pemberian pelayanan yang berkualitas atau pelayanan prima yang tercermin dari transparansi yakni 
pelayanan yang bersifat terbuka, mudah dan dapat diakses oleh semua pihak yang membutuhkan dan disediakan secara memadai serta mudah dimengerti [2].

Akuntabilitas yakni pelayanan yang dapat dipertanggung jawabkan sesuai dengan ketentuan peraturan perundang-undangan. Kondisional yakni pelayanan yang sesuai dengan kondisi dan kemampuan pemberi dan penerima pelayanan dengan tetap berpegang pada prinsip efisiensi dan efektifitas. Partisipatif yakni pelayanan yang dapat mendorong peran serta masyarakat dalam penyelenggaraan pelayanan publik dengan memperhatikan aspirasi, kebutuhan dan harapan masyarakat. Kesamaan hak yakni pelayanan yang tidak melakukan diskriminasi dilihat dari aspek apapun khususnya suku, ras, agama, golongan, status sosial dan lain-lain. Keseimbangan hak dan kewajiban, yakni pelayanan yang mempertimbangkan aspek keadilan antara pemberi dan penerima layanan publik (Kesejahteraan and Services, 2014).

Dengan berlandaskan pemikiran terhadap permasalahan yang dihadapi oleh masyarakat sebagai pengguna layanan sebagai upaya untuk memperbaiki berbagai kelemahan dan mengantisipasi kekurangan terhadap kualitas layanan publik khususnya bidang perizinan, pemerintah membentuk lembaga Pelayanan Terpadu Satu Pintu. Yang bertujuan untuk memperbaiki iklim investasi untuk mendorong pertumbuhan ekonomi dan memberikan perhatian terhadap usaha mikro, kecil dan menengah. Sehubungan dengan hal tersebut. Pelayanan Terpadu Satu Pintu dan satu atap sendiri mempunyai tujuan untuk memperpendek proses pelayanan, mewujudkan proses pelayanan yang cepat, mudah, murah, transparan, pasti dan terjangkau serta mendekatkan dan memberikan pelayanan yang lebih luas kepada masyarakat.

Dengan visi "Prima dalam Pelayanan Perizinan", Badan Pelayanan Perizinan Terpadu memberikan pelayanan kepada masyarakat dengan sistem terpadu satu pintu (One Stop Services) guna mendukung pembangunan dan investasi dengan memberikan pelayanan yang mudah, murah, cepat, tidak berbeli-belit dengan didukung aturan hukum, mekanisme, sistem, prosedur, kesiapan sumber daya manusia serta sarana dan prasarana demi terciptanya pelayanan perizinan yang optimal. Dalam kegiatannya Badan Pelayanan Perizinan Terpadu menjalankan sebagian fungsi penanaman modal yaitu memberikan persetujuan atau perizinan untuk melakukan penanaman modal. Namun fungsi penanaman modal yang lain masih dilaksanakan oleh Kantor Penanaman Modal, karena Badan Pelayanan Perizinan Terpadu belum menjadi satu dengan instansi penanaman modal. 
Disadari bahwa Negara Republik Indonesia memiliki berbagai potensi daerah yang dapat mendorong investasi perekonomian Indonesia.

Dalam pelaksanaannya tentu diperlukan strategi yang tepat agar investasi dapat meningkat, salah satunya dengan perbaikan pelayanan publik di bidang perizinan. Penyelenggaraan Pelayanan Terpadu Satu Pintu merupakan salah satu upaya agar pelayanan publik bidang perizinan semakin efektif. Sebuah pelayanan publik bisa dikatakan efektif jika sesuai dengan sasaran dan tujuan penyelenggaraan pelayanan publik tersebut yaitu kepuasan masyarakat. Dengan tujuan dan sasaran yang tepat, penyelenggaraan Pelayanan Terpadu Satu Pintu dapat tercapai efektivitasnya. (Ismayanti, 2015)

Menurut Drucker dalam bukunya Moenir arti efisiensi dan efektivitas adalah“... that is, the ability to get things done correctly - is an "input output concept. An efficient manager is one who achieves outputs or result, that measure up to the inputs (labor, materias and time) used to achieve. Managers who are able to minimalize the cost of the resources they use to atteain their goals are afficiently" Dan pengertian efektivitas, dia mengatakan"Effectiveness, on the other hand, is the ability to choose appropriate objectives. An effective manager is one who selects the right things to get done"[3].

Dari pengertian diatas dapat disimpulkan, efisiensi adalah melakukan atau mengerjakan suatu pekerjaan dengan cara yang benar. Sedangkan efektifitas adalah melakukan atau mengerjakan sesuatu tepat pada sasaran atau tujuannya. Bagi para pemimpin, sangatlah penting menemukan cara yang tepat untuk dilakukan dan memfokuskan daya dan usaha untuk pekerjaan tersebut agar tercapai tujuan yang diinginkan. Dengan pengertian lain, efektivitas adalah sebagai suatu ukuran yang menyatakan tingkat pencapaian sasaran atau tujuan (kuantitas, kualitas dan waktu). Dalam bentuk perbandingan aktivitas adalah hasil nyata dibandingkan dengan hasil yang diharapkan. Dari teori di atas disimpulkan bahwa efektivitas Badan Pelayanan Perizinan Terpadu dapat tercapai apabila telah sesuai dengan tujuan dan sasaran organisasi dengan melaksanakan pekerjaan dengan benar. Namun dalam pencapaiannya ada beberapa hal yang dapat menyebabkan penyelenggaraan Pelayanan Terpadu Satu Pintu kurang efektif.

Antara lain pelayanan perizinan dianggap sulit atau berbelit-belit dan membutuhkan waktu yang lama. Keluhan biaya atau retribusi yang kurang transparan yang mengakibatkan anggapan bahwa pengurusan perizinan menjadi mahal. Rendahnya kualitas pelayanan publik khususnya bidang perizinan menjadi salah satu sorotan 
masyarakat pada birokrasi pemerintahan. Seharusnya dengan adanya Pelayanan Terpadu Satu Pintu, pelayanan perizinan menjadi mudah, transparan, bebas biaya diluar retribusi, tepat waktu sesuai dengan Standar Operasional Prosedur. Keamanan dan kenyamanan masyarakat dijamin sesuai dengan Standar Pelayanan.

Bahkan untuk meningkatkan pengawasan terhadap pelayanan publik, pemerintah membentuk Komisi Pelayanan Publik (KPP), namun komisi ini tidak digunakan masyarakat. Jika keadaan tersebut terus dibiarkan tanpa ada kepastian penyelesaian dapat memperburuk investasi. Penulisan jurnal ini membahas efektivitas penyelenggaraan pelayanan terpadu satu pintu di berbagai daerah Negara Republik Indonesia. Tujuannya adalah untuk menelaah, menganalisa dan menggambarkan efektivitas penyelenggaraan pelayanan terpadu satu pintu serta menggambarkan faktor pendukung dan penghambat efektivitas penyelenggaraan pelayanan terpadu satu pintu tersebut.

Berdasarkan hal tersebut maka dapat di dilakukan perumusan masalah yaitu bagaimana efektivitas penyelenggaraan pelayanan terpadu satu pintu dalam sistem pemerintahan Negara Republik Indonesia dan apakah faktor pendukung dan penghambat efektivitas penyelenggaraan pelayanan terpadu satu pintu tersebut. Manfaat dari penulisan jurnal ini yaitu dapat memberikan sumbangan pemahaman tentang efektivitas penyelenggaraan pelayanan terpadu satu pintu dan satu atap.

\section{B. Pembahasan}

\section{Pelayanan Publik}

Secara etimologis, pelayanan ialah "usaha melayani kebutuhan orang lain". Pelayanan pada dasarnya adalah kegiatan yang ditawarkan kepada konsumen atau pelanggan yang dilayani, yang bersifat tidak berwujud dan tidak dapat dimiliki. Pelayanan publik yang dimaksud dalam Keputusan Menpan Nomor 63 Tahun 2003 adalah "segala kegiatan pelayanan yang dilaksanakan oleh penyelenggara pelayanan publik sebagai upaya pemenuhan kebutuhan penerima pelayanan maupun pelaksanaan ketentuan peraturan perundang-undangan" (Negara, 2003). Sejalan dengan Undang Undang Nomor 25 Tentang Pelayanan Publik memaknai bahwa "pelayanan publik adalah kegiatan atau rangkaian kegiatan dalam rangka pemenuhan kebutuhan dasar sesuai dengan hak-hak sipil setiap warga negara dan penduduk atas suatu barang, jasa, dan atau pelayanan administrasi yang disediakan oleh penyelenggara pelayanan publik" (Indonesia, 2009). 
Publik pada dasarnya berasal dari bahasa Inggris "public" yang berarti umum, rakyat umum, orang banyak dan rakyat. Nampaknya kata "publik" diterjemahkan oleh beberapa kalangan berbeda- beda sebagaimana kepentingan mereka. Berikut beberapa defenisi menurut para ahli Syafie dkk, ,mengatakan bahwa pubik adalah sejumlah manusia yang memiliki kebersamaan berpikir, perasaan, harapan, sikap dan tindakan yang benar dan baik berdasarkan nilai-nilai norma yang mereka miliki. George Fredrickson, menjelaskan konsep "public" dalam lima perspektif, yaitu : 1). public sebagai kelompok kepentingan, yaitu public dilihat sebagai manifestasi dari interaksi kelompok yang melahirkan kepentingan masyarakat, 2). public sebagai pemilih yang rasional, yaitu masyarakat terdiri atas individu- individu yang berusaha memenuhi kebutuhan dan kepentingan sendiri, 3). public sebagai perwakilan kepentingan masyarakat, yaitu kepentingan public diwakili melalui suara, 4). public sebagai konsumen, yaitu konsumen sebenarnya tidak terdiri dari individu-individu yang tidak berhubungan satu sama lain, namun dalam jumlah yang cukup besar mereka menimbulkan tuntutan pelayanan birokrasi. Karena itu posisinya dianggap juga dianggap sebagai public, dan 5). public sebagai warga Negara dalam seluruh proses penyelenggaraan pemerintahan dipandang sebagai sesuatu yang paling penting. (Publik and Suherlan dan Budhiono, 1997)

Pelayanan publik menurut Sinambela adalah setiap kegiatan yang dilakukan oleh pemerintah terhadap sejumlah manusia yang memiliki setiap kegiatan yang menguntungkan dalam suatu kumpulan atau kesatuan, dan menawarkan kepuasan meskipun hasilnya tidak terikat pada suatu produk secara fisik [2]. Pelayanan publik adalah pemberian pelayanan (melayani) keperluan orang lain atau masyarakat yang mempunyai kepentingan pada organisasi itu sesuai dengan aturan pokok dan tata cara yang telah ditetapkan. Jadi, Pelayanan publik dapat diartikan sebagai pemberian layanan(melayani) keperluan orang atau masyarakat yang mempunyaikepentingan pada organisasi itu sesuai dengan aturan pokok dantata cara yang telah ditetapkan. Pelayanan adalah suatu kegiatan atau urutan kegiatan yang terjadi dalam interaksi langsung antara seseorang dengan orang lain atau mesin secara fisik dan menyediakan kepuasan pelanggan.

Pelayanan adalah setiap kegiatan atas unjuk kerja yang ditawarkan oleh salah satu pihak kepada pihak lain yang secara prinsip intangileble dan tidak menyebabkan pemindahan kepemilikan apapun, produksinya bisa juga tidak terikat pada suatu produk fisik [4]. Dari uraian diatas dapat ditarik kesimpulan bahwa, sistem pelayanan adalah 
suatu kesatuan usaha yang dinamis yang terdiri dari berbagai bagian yang berkaitan secara teratur, diikuti dengan unjuk kerja yang ditawarkan oleh satu pihak terhadap pihak lain dengan memberi manfaat, guna mencapai suatu tujuan. Pelayanan publik atau pelayanan umum dapat didefinisikan sebagai segala bentuk jasa pelayanan, baik dalam bentuk barang publik maupun jasa publik yang pada prinsipnya menjadi tanggung jawab dan dilaksanakan oleh Instansi Pemerintah di Pusat, di Daerah, dan di lingkungan Badan Usaha Milik Negara atau Badan Usaha Milik Daerah, dalam rangka upaya pemenuhan kebutuhan masyarakat maupun dalam rangka pelaksanaan ketentuan peraturan perundang-undangan (Suryono, Agus, 2001).

Pelayanan publik dapat diartikan sebagai pemberian layanan(melayani) keperluan orang atau masyarakat yang mempunyaikepentingan pada organisasi itu sesuai dengan aturan pokok dantata cara yang telah ditetapkan. Sebagaimana telah dikemukakan terdahulu bahwa pemerintahan pada hakekatnya adalah pelayanan kepada masyarakat. Ia tidaklah diadakan untuk melayani dirinya sendiri,tetapi untuk melayani masyarakat serta menciptakan kondisi yang memungkinkan setiap anggota masyarakat mengembangkan kemampuan dan kreativitasnya demi mencapai tujuan bersama. Karenanya birokrasi publik berkewajiban dan bertanggung jawab untuk memberikan layanan baik dan profesional.

\section{Pengertian pelayanan terpadu satu pintu}

Pengertian Penyelenggaraan Pelayanan Terpadu Satu Pintu (PPTSP) adalah kegiatan penyelenggaraan jasa perizinan dan non-perizinan, yang proses pengelolaannya di mulai dari tahap permohonan sampai ke tahap penerbitan ijin dokumen, dilakukan secara terpadu dalam satu tempat. Dengan konsep ini, pemohon cukup datang ke satu tempat dan bertemu dengan petugas front office saja. Hal ini dapat meminimalisasikan interaksi antara pemohon dengan petugas perizinan dan menghindari pungutan-pungutan tidak resmi yang seringkali terjadi dalam proses pelayanan (Publik and Suherlan dan Budhiono, 1997). Pembentukan Penyelenggaraan Pelayanan Terpadu Satu Pintu (PPTSP) pada dasarnya ditujukan untuk menyederhanakan birokrasi pelayanan perizinan dan non-perizinan dalam bentuk :

1. Mempercepat waktu pelayanan dengan mengurangi tahapan-tahapan dalam pelayanan yang kurang penting.

2. Koordinasi yang lebih baik juga akan sangat berpengaruh terhadap percepatan layanan perizinan. 
3. Menekan biaya pelayanan izin usaha, selain pengurangan tahapan, pengurangan biaya juga dapat dilakukan dengan membuat prosedur pelayanan serta biaya resmi menjadi lebih transparan.

4. Menyederhanakan persyaratan izin usaha industri, dengan mengembangkan sistem pelayanan paralel dan akan ditemukan persyaratan-persyaratan yang tumpang tindih, sehingga dapat dilakukan penyederhanaan persyaratan. Hal ini juga berdampak langsung terhadap pengurangan biaya dan waktu.

Pelayanan perizinan dengan sistem terpadu satu pintu (one stop service) ini membuat waktu pembuatan izin menjadi lebih singkat. Pasalnya, dengan pengurusan administrasi berbasis teknologi informasi, input data cukup dilakukan sekali dan administrasi bisa dilakukan simultan. Dengan adanya kelembagaan pelayanan terpadu satu pintu, seluruh perizinan dan nonperizinan yang menjadi kewenangan kabupaten/kota dapat terlayani dalam satu lembaga. Harapan yang ingin dicapai adalah mendorong pertumbuhan ekonomi melalui peningkatan investasi dengan memberikan perhatian yang lebih besar pada peran usaha mikro, kecil, dan menengah. Tujuannya adalah meningkatkan kualitas layanan publik (Pasolong, Harbani, 2013).

Oleh karena itu, diharapkan terwujud pelayanan publik yang cepat murah, mudah, transparan, pasti, dan terjangkau, di samping untuk meningkatkan hak-hak masyarakat terhadap pelayanan publik. Bentuk pelayanan terpadu ini bisa berbentuk kantor, dinas, ataupun badan. Dalam penyelenggaraannya, bupati/wali kota wajib melakukan penyederhanaan layanan meliputi :

1. pelayanan atas permohonan perizinan dan non perizinan dilakukan oleh Penyelenggaraan Pelayanan Terpadu Satu Pintu (PPTSP);

2. percepatan waktu proses penyelesaian pelayanan tidak melebihi standar waktu yang telah ditetapkan dalam peraturan daerah;

3. kepastian biaya pelayanan tidak melebihi dari ketentuan yang telah ditetapkan dalam peraturan daerah;

4. kejelasan prosedur pelayanan dapat ditelusuri dan diketahui setiap tahapan proses pemberian perizinan dan non perizinan sesuai dengan urutan prosedurnya;

5. mengurangi berkas kelengkapan permohonan perizinan yang sama untuk dua atau Lebih permohonan perizinan;

6. pembebasan biaya perizinan bagi Usaha Mikro Kecil Menengah (UMKM) yang ingin memulai usaha baru sesuai dengan peraturan yang berlaku; dan 
7. pemberian hak kepada masyarakat untuk memperoleh informasi dalam kaitannya dengan penyelenggaraan pelayanan Lingkup tugas PPTSP meliputi pemberian pelayanan atas semua hentuk pelayanan perizinan dan non perizinan yang menjadi kewenangan Kabupaten / Kota.

Selain itu PPTSP mengeiola administrasi perizinan dan non perizinan dengan mengacu pada prinsip koordinasi, integrasi, sinkronisasi, dan kearnanan berkas. Dalam pengertian sempit, pelayanan terpadu dapat berarti sebagai satu instansi pemerintah yang memiliki semua otoritas yang diperlukan untuk memberi pelbagai perizinan (licenses, permits, approvals dan clearances) (Sedarmayanti, 2013). Tanpa otoritas yang mampu menangani semua urusan tersebut instansi pemerintah tidak dapat mengatur pelbagai pengaturan selama proses. Oleh sebab itu, dalam hal ini instansi tersebut tidak dapat menyediakan semua bentuk perizinan yang diperlukan dalam berbagai tingkat administrasi, sehingga harus bergantung pada otoritas lain.

\section{Asas dan prinsip pelayanan publik}

Pada dasarnya pelayanan publik dilaksanakan dalam suatu rangkaian kegiatan terpadu yang bersifat sederhana, terbuka, lancar, tepat, lengkap, wajar, dan terjangkau. Oleh sebab itu setidaknya mengandung asas-asas antara lain:

1. Hak dan kewajiban, baik bagi pemberi dan penerima pelayanan publik tersebut, harus jelas dan diketahui dengan baik oleh masing-masing pihak, sehingga tidak ada keragu-raguan dalam pelaksanaannya.

2. Pengaturan setiap bentuk pelayanan umum harus disesuaikan dengan kondisi kebutuhan dan kemampuan masyarakat untuk membayar, berdasarkan ketentuan perundang-undangan yang berlaku, dengan tetap berpegang pada efisiensi dan efektifitasnya.

3. Mutu proses keluaran dan hasil pelayanan publik tersebut harus diupayakan agar dapat memberikan keamanan, kenyamanan, kelancaran dan kepastian hukum yang dapat dipertanggungjawabkan.

4. Apabila pelayanan publik yang diselenggarakan oleh Instansi atau Lembaga Pemerintah atau Pemerintahan "terpaksa harus mahal", maka Instansi atau Lembaga Pemerintah atau Pemerintahan yang bersangkutan berkewajiban "memberi peluang" kepada masyarakat untuk ikut menyelenggarakannya, sesuai dengan peraturan perundang-undangan yang berlaku (Ermalena and Suardita, 2009). 
Asas Pelayanan Publik adalah untuk memberikan pelayanan yang memuaskan bagi pengguna jasa, penyelenggara pelayanan harus memenuhi asas-asas pelayanan sebagai berikut (Negara, 2003) : Transparansi, Akuntabilitas, Kondisional, Partisipatif, Kesamaan Hak, Keseimbangan Hak dan Kewajiban. Penyelenggaraan Pelayanan Publik perlu memperhatikan dan menerapkan prinsip, standar, pola penyelenggaraan, biaya, pelayanan bagi penyandang cacat, lanjut usia, wanita hamil dan balita, pelayanan khusus, biro jasa pelayanan, tingkat kepuasan masyarakat, pengawasan penyelenggaraan, penyelesaian pengaduan sengketa, serta evaluasi kinerja penyelenggaraa pelayanan publik. Penyelenggaraan pelayanan publik harus memenuhi beberapa prinsip sebagai berikut: Kesederhanaan; Kejelasan; Kepastian Waktu; Akurasi; Keamanan; Tanggung Jawab; Kelengkapan Sarana dan Prasarana; Kemudahan Akses; Kedisiplinan, Kesopanan dan Keramahan; Kenyamanan.

Standar Pelayanan Publik adalah setiap penyelenggaraan pelayanan publik harus memiliki standar pelayanan dan dipublikasikan sebagai jaminan adanya kepastian bagi penerima pelayanan. Standar pelayanan merupakan ukuran yang dibakukan dalam penyelenggaraan pelayanan publik yang wajib ditaati oleh pemberi dan penerima pelayanan tersebut (Miles, B. Mathew, 2014). Standar pelayanan publik sekurangkurangnya meliputi: Prosedur Pelayanan, Waktu Penyelesaian, Biaya Pelayanan, Produk Pelayanan, Sarana dan Prasarana, Kompetensi petugas pemberi pelayanan

\section{Pola penyelenggara pelayanan publik}

Penyelenggaraan pelayanan publik yang sesuai dengan bentuk dan sifatnya, menurut Keputusan Menteri Negara Pendayagunaan Aparatur Negara Nomor 63 Tahun 2003 tentang Pedoman Umum Penyelenggaraan Pelayanan Publik terdapat empat pola pelayanan, yaitu:

a. Pola Pelayanan Fungsional, yaitu pola pelayanan publik diberikan oleh penyelenggaraan pelayanan sesuai dengan tugas, fungsi dan kewenangannya. Misalnya untuk pelayanan pajak akan ditangani unit organisasi yang berfungsi melakukan pemungutan pajak, contohnya Kantor Pelayanan Pajak Daerah (KPPD).

b. Pola Pelayanan Terpusat, yaitu pola pelayanan yang diberikan secara tunggal oleh penyelenggara pelayanan terkait lainnya yang bersangkutan. Misalnya yaitu pengurusan pelayanan paspor oleh kantor imigrasi dan pelayanan pembuatan akte kelahiran oleh Kantor Catatan Sipil.

c. Pola Pelayanan Terpadu yang dibagi ke dalam dua bagian pola pelayanan, yaitu: 
- Pola Pelayanan Terpadu Satu Atap

Pola Pelayanan Terpadu Satu Atap diselenggarakan dalam satu tempat yang meliputi berbagai jenis pelayanan yang tidak mempunyai keterkaitan proses dan dilayani melalui beberapa pintu. Terhadap jenis pelayanan yang sudah dekat dengan masyarakat tidak perlu disatu atapkan.

- Pola Pelayanan Terpadu Satu Pintu

Pola Pelayanan Terpadu Satu Pintu diselenggarakan pada satu tempat yang memiliki keterkaitan proses dan dilayani melalui satu pintu. Misalnya pelayanan pembuatan Bukti Pemilik Kendaraan Bermotor (BPKB) dan Surat Tanda Nomor Kendaraan (STNK) (Khalimah, 2013).

\section{Simpulan}

Kebijakan sistem PTSP dapat saja sebagai alternatif perbaikan dari Sistem Pelayanan Satu Atap. Namun demikian, sistem baru ini tidak akan memberikan perubahan yang diharapkan, jika tidak dapat menunjukan adanya efisien dalam pelayanan, memiliki standar waktu dan biaya yang jelas, memiliki prosedur pelayanan yang sederhana, dan mudah diakses oleh yang membutuhkan. Untuk mewujudkan sistem pelayanan administrasi yang memiliki karakter demikian, salah satu strategi yang perlu dikembangkan dalam PTSP adalah melalui pembentukan Unit Pelayanan (UP) yang memiliki kewenangan khusus dalam pemberian perizinan. UP tersebut dapat didesain dalam beberapa bentuk, antara lain: Pertama, Merupakan Satuan/Unit Kerja tertentu, yang memiliki kewenangan untuk memberikan pelayanan perizinan penanaman modal secara terpusat. Satuan/Unit Kerja ini memiliki kewenangan untuk memproses dan menerbitkan berbagai perizinan yang merupakan pelimpahan sebagian dari kewenangan unit-unit kerja yang melayani perizinan. Kedua, Merupakan Satuan/Unit Kerja yang memberikan pelayanan perizinan penanaman modal. Satuan/Unit kerja ini memiliki front line yang berfungsi untuk menerima semua permohonan perizinan penanaman modal di daerah dan back line yang memiliki hubungan kerja dengan satuan/unit kerja yang secara fungsional menerbitkan perizinan.

Kedua bentuk UP tersebut dirancang untuk mengurangi jalur birokrasi dan menyederhanakan prosedur dalam pelayanan penanaman modal di daerah. Dengan demikian, diharapkan waktu dan biaya yang diperlukan untuk pengurusan perizinan penanaman modal di daerah akan lebih cepat dan murah. Selanjutnya, terkait dengan 
upaya perbaikan iklim penanaman modal di daerah, pembenahan kelembagaan ini juga harus didukung oleh perbaikan dalam standar pelayanan penanaman modal, kualitas sumber daya aparatur yang menangani bidang tersebut, dan komitmen para pimpinan di daerah

\section{Daftar Pustaka}

Ermalena, R. and Suardita, I. K. (2009) 'Penerapan Asas Good Governance Dalam Pelayanan Publik Di Indonesia Berdasarkan Undang-Undang Nomor 25 Tahun 2009', Bagian Hukum Pemerintahan Fakultas Hukum Universitas Udayana, pp. 1-5.

Indonesia, P. R. (2009) 'UU Nomor 25 Tahun 2009 Tentang"Pelayanan Publik"', UU Nomor 25 Tahun 2009 Tentang"Pelayanan Publik".

Ismayanti, L. (2015) 'Efektivitas Penyelenggaraan Pelayanan Terpadu Satu Pintu di Kabupaten Malang', JISIP: Jurnal Ilmu Sosial dan Ilmu Politik, 4(2), pp. 290-300.

Khalimah, Sos, Diponegoro (2013) 'Implikasi Penerapan One Stop Service Pelayanan Investasi Di Kabupaten Kudus', pp. 3-6.

Kesejahteraan, N. and Services, O. (2014) 'Penyelenggaraan Pelayanan Publik Di Indonesia , Sudahkah Berlandaskan Konsep “ Welfare State '?'

Negara, M. P. A. (2003) 'Keputusan Menteri Pendayagunaan Aparatur Negara Nomor 63/KEP/M.PAN/7/2003 Tentang Pedoman Umum Penyelenggaraan Pelayanan Publik', p. 21.

Publik, M. P. and Suherlan dan Budhiono, 2013: 130) (1997) 'Perkembangan Teori tentang Publik', pp. 1-14. doi: 10.1016/S1570-0232(03)00565-8.

Miles, B. Mathew., Huberman, A. Michael dan Saldana, Johnny. 2014. Qualitative Data Analysis A Methods Source Book. Third Edition. Arizona State University, America.

Suryono, Agus. 2001. Jurnal Administrasi Negara Volume I No. 2 Tentang Manajemen Pelayanan Publik. Malang. FIA.

Ratminto \& Winarsih. 2005. Manajemen Pelayanan. Jogjakarta: Pustaka Belajar

Suwardi. 2011. Kualitas Pelayanan Perizinan pada Kantor Pelayanan Perizinan Terpadu (KPPT) Kota Surakarta Provinsi Jawa Tengah. Skripsi. Surakarta

Winarno, Budi. 2002. Teori dan Proses Kebijakan Publik. Yogyakarta: Media Pressindo.

Sedarmayanti. 2013. Reformasi Administrasi Publik, Reformasi Birokrasi dan Kepemimpinan Masa Depan. Bandung: Refika Aditama

Quade, E. E. 1999. Analysis for Public Decisions. New York: Elsevier.

Y. Sri Pudyatmoko, Jurnal Hukum Pro Justitia, Oktober 2007, Volume 25 No. 4, Hlm. 363-364. 